\title{
Analyse af kræevende syntaks i danskfagets tekster
}

\section{MAR'TIN HAUERBERG OLSEN OG MADS POULSEN}

\begin{abstract}
Formålet med artiklen er at give overblik over omfanget af syntaks, der kan være krævende at forstå, i en stikprøve af danskfagets undervisningstekster. Artiklen opsummerer tre grunde til, at en sætnings syntaks, dvs. sætningsbygning, kan være krævende: uvante (ikke-kanoniske) konstruktioner, kompleksitet og økonomisering med sproglige signaler. Undersøgelsen af undervisningsteksterne viser, at samtlige krævende syntakselementer optræder i tekster fra indskolingen til udskolingen. Selv yngre elever kan møde krævende syntaks i danskfagets tekster og ofte i omtrent samme omfang som ældre elever. Det er imidlertid en væsentlig pointe, at selvom en sætning indeholder krævende syntaks, så behøver den ikke nødvendigvis at være svær at forstå i praksis. Uvante (dvs. ikke-kanoniske) sætningskonstruktioner som passiver, OVS-sætninger og objektrelativer bruges ofte i psykolingvistiske undersøgelser, hvor de har vist sig at volde både børn og voksne vanskeligheder, når forståelsen ikke er støttet af baggrundsviden. Denne undersøgelse fandt, at uvante konstruktioner som oftest er støttet af baggrundsviden i undervisningsteksterne - i modsætning til i psykolingvistiske forsøg - således at fortolkningen ikke afhænger af syntaksen alene. Manglende kendskab til netop sådanne konstruktioner er derfor nok kun i begrænset omfang årsag til forståelsesvanskeligheder ved danskfagets tekster.
\end{abstract}

EMNEORD: læseforståelse, syntaktisk kompleksitet, læsbarhed, danskfagets tekster

\section{INDLEDNING}

Når man skal læse og forstå en tekst, kan en række sproglige forhold i teksten udfordre. Det er fx en udfordring for forståelsen, hvis der er ord, man ikke kender, eller hvis teksten forudsætter baggrundsviden, som man ikke har. Teksten kan også kræve, at læseren selv læser mellem linjerne. Men sætningernes syntaks kan også stille krav til læseren. Lange sætninger kan fx stille krav til, at læseren forholder mange ordbe- 
tydninger til hinanden på samme tid. Inde i sætninger giver ordrækkefølge og bøjning (morfosyntaks) signaler om, hvordan ordbetydningerne skal relateres til hinanden. Men nogle sætningsstrukturer kan være sværere at forstå end andre. Passivsætninger kan fx nogle gange volde både børn og voksne vanskeligheder i den forstand, at de er længere tid om at læse dem og mere tilbøjelige til at misforstå dem (Ferreira 2003, Grandjean \& Poulsen 2017).

Formålet med denne artikel er at give et overblik over omfanget af krævende syntaks i danskfagets undervisningstekster i grundskolen. Således afgrænser og eksemplificerer artiklen forskellige typer af krævende syntaks og undersøger udbredelsen i et udvalg af dansktekster.

\subsection{Kravende syntaks}

Nogle sætningsbygninger kan være mere krævende for læseren at forstå end andre. Det kan der være flere forskellige grunde til. Fx er det oplagt, at antallet og omfanget af syntaktiske enheder (ord og syntagmer), der skal relateres til hinanden, kan betyde noget for, hvor vanskelig sætningen er at forstå, fx:

(1) Det blev læst op en Søndag efter Gudstjenesten, af Sognefogdens Søn, ved Stævningsstenen uden for Kirken: at Frøken Irene Holm, Danserinde fra det kongelige Theater, den første November i Kroen vilde aabne sine Kursus i Holdning, Dans og Bevægelser, saa vel for Børn som for Viderekomne, Damer og Herrer, saafremt et tilstrækeligt antal Deltagere tegnedes. (Bang 2006: 576)

Ideen er bredt accepteret i skolepraksis, bl.a. ved at mange begynderlæsebøger forsynes med oplysning om lix-niveau (fx www.frilaesning. dk og www.bog-ide.dk), som afhænger af antallet af ord pr. periode og andelen af ord længere end seks bogstaver (Björnsson 1971).

Omfanget kan også blive mere krævende, hvis der optræder ledsætninger på bestemte pladser i sætningen. Hvis en ledsætning fx optræder i sætningens forfelt, kan det udfordre læseren (Arnbak \& Gandil 2010, Jacobsen \& Skyum-Nielsen 2007). Det samme gælder ledsætninger indskudt mellem en nominalkerne og et verbal, fx: 
(2) Mordhorst, som under afsyngelsen af sangen var gruppeleder, og som gav den ansatte en undskyldning, mener, det var helt legitimt (Winther 2018; vores fremhævning).

Ledsætningsindskud af denne type har i særlig grad potentiale til at sætte læserens syntaksforarbejdning under pres (Dalby et al. 1989, Scott \& Balthazar 2010).

Andre sætninger kan være krævende, fordi strukturen er uvant (dvs. ikke-kanonisk). Ordrækkefølgen i en sammenhængende sætning skulle gerne støtte læseren i at relatere de enkelte ordbetydninger til hinanden i en passende mental model, uden at læseren skal gætte sig til det hele. Sætning (3) har således en vant (kanonisk) struktur, hvor ordrækkefølgen, aktivformen og kasusmarkeringen af objektet ('hende') samstemmende signalerer, at det er Jonas, der puffer. Selvom både subjekt og objekt kan placeres i forfeltet, så ser man oftest, at subjektet er placeret før objektet (Thomsen \& Kristensen 2014), og at subjektet har den semantiske rolle agens og ikke patiens.

(3) Jonas puffede hende.

Det er veletableret, at læsere indføjer hvert nyt ord i sætningen i en lobende opdateret tolkning af sætningens betydning på baggrund af blandt andet syntakssignaler i stedet for at vente, til hele sætningen er færdig (Just \& Carpenter 1980, Kizach et al. 2013). Således aflastes behovet for at holde en masse løsrevne ordbetydninger i hukommelsen, indtil sætningen er læst til ende. Syntaks kan med andre ord bidrage til at aflaste læserens hukommelse. Aflastningseffekten afhænger naturligvis af, om læseren i tilstrækkeligt omfang har tilegnet sig den tavse viden om de relevante syntaktiske konventioner til at kunne bruge dem automatisk og effektivt i en læsesituation. Det kan ikke altid tages for givet. En række psykolingvistiske studier viser, at uvante sætningskonstruktioner forstås langsommere og er forbundet med flere fejlfortolkninger end vante (Ferreira 2003, Grandjean \& Poulsen 2017, Thomsen \& Kristensen 2014, Thomsen \& Poulsen 2015, Wells et al. 2009). Det er blandt andet tilfældet i passivkonstruktioner, hvor subjektet mod vanen er patiens (4). I OVS-sætninger signalerer subjektet i henhold til 
vanen agens, men er placeret efter objektet (5), og i objektrelativsætninger står objektet/patiens for ledsætningsverbet inden subjektet (6).

(4) Hun blev puffet af Jonas.

(5) Hende puffede Jonas.

(6) Drengen så pigen, som Jonas puffede.

Endelig argumenterer vi for, at det er muligt, at sproglig 'økonomisering' (hvor der spares på ordene eller sætningerne) kan blive krævende, fx ved ellipser (7), fordi syntaksen undersignalerer, hvordan sætningsbetydningen skal etableres.

(7) Uden på vores hus i landsbyen kan man ikke se, at min far er den rigeste - kun indeni, for vi har de fineste tæpper. ( B r a n ner 1964: 71; vores fremhævning)

Læseren skal i højere grad selv kæde betydningselementerne sammen ved at knytte tekstbånd til omkringstående sætninger og integrere kontekstuel viden.

Nominaliseringer af typen verbalsubstantiv udgør også en form for sproglig økonomisering ved at udtrykke verbalhandlinger (8) i en substantiveret form (9) med en eller flere af de semantiske roller implicit. Nominaliseringer er et vigtigt redskab i fagtekster, men fremhæves også som udfordrende i gennemgange af særlige karaktertræk, som kan volde elever vanskeligheder (Fang 2012, Snow 2010, Uccelli et al. 2015).

(8) Jonas så skovarbejderen fælde træet.

(9) Jonas så træfældningen.

Med ovenstående sammenfatter vi krævende syntaks som: uvante, det vil sige ikke-kanoniske, sætningskonstruktioner, kompleks sætningsbygning samt sproglig økonomisering, der indebærer syntaktisk undersignalering. 


\subsection{Udgør uvante satningskonstruktioner et problem i praksis?}

Det er ikke givet, at uvante sætningskonstruktioner volder problemer i praksis, selvom de fx gør det i psykolingvistiske test, der ofte er lavet under betingelser, hvor læseren er fuldkommen afhængig af den syntaktiske information for at forstå budskabet. I rigtige tekster er der ofte betydelig redundans, således at forståelsen bliver støttet af konteksten eller læserens baggrundsviden. I konkrete sætninger kan den syntaktiske information være nærmest overflødig:

(10) Huset er tegnet og bygget af arkitekten Antonio Gaudí, der levede 1852-1926. (May \& Arne-Hansen 2009: 100)

Vores baggrundsviden etablerer en forventning om, at det er arkitekter, der tegner og bygger huse, ikke omvendt. Her behøver vi ikke effektiv forarbejdning af de syntaktiske signaler for at etablere den rigtige forståelse. Sådanne sætninger kaldes semantisk irreversible, fordi man ikke kan bytte rundt på de semantiske roller (fx med huset som agens), uden at det strider mod ens viden om verden. I en semantisk reversibel sætning kan rollerne byttes rundt, uden at det strider mod ens viden om verden, fx Drengen puffede pigen. Undersøgelser har da også vist, at man har lettere ved at forstå semantisk irreversible end reversible sætninger (Ferreira 2003, Slobin 1966), sandsynligvis fordi vores sætningsforståelsesproces i vid udstrækning også påvirkes af vores indholdsforventninger, ikke kun de syntaktiske detaljer (Karimi \& Ferreira 2016). Danske undersøgelser tyder da også på, at semantisk irreversible sætninger i tekster generelt ikke volder store vanskeligheder for voksne (Balling 2013, Ingemansson \& Jensen 2015; se Grandjean \& Poulsen 2017 for diskussion).

Både danske og internationale undersøgelser har imidlertid vist, at der er en relativt stærk korrelation mellem, hvor godt skolebørn i test forstår semantisk reversible sætninger, og hvor godt de forstår tekster i det hele taget (Soerensen Duncan et al. under udgivelse, Grandjean \& Poulsen 2017, Language and Reading Research Consortium \& Logan 2017, Silva \& Cain 2015). Nogle undersøgelser tyder ydermere på, at det især er forståelsen af uvante konstruktioner, som korrelerer med forstålsen af tekster (Poulsen \& Gravgaard 2017, Poulsen et al. under 
udgivelse). Det rejser den mulighed, at manglende færdighed i at forstå bl.a. netop de uvante konstruktioner er årsagen til visse elevers udfordrede læseforståelse. Det kunne give anledning til opprioritering af undervisning specifikt i disse konstruktioner. En anden mulig forklaring er imidlertid, at de uvante konstruktioner blot er gode til at afdække svagheder i elevers evne til at udnytte syntaktiske informationer generelt (se diskussion i Grandjean \& Poulsen 2017). I så fald vil det nok være nødvendigt at sætte bredere ind i undervisning i sætningsbygning og -forståelse. Korrelationsundersøgelser giver imidlertid ikke evidens for, hvad der er årsag til sammenhængen, og derfor er de praktiske implikationer ikke klare.

For at vurdere den praktiske betydning af kendskabet til ikke-kanoniske konstruktioner som $\mathrm{fx}$ passiver kan det være nyttigt at vide, hvor tit elever konfronteres med dem i deres læremidler, og hvor tit disse sætninger er reversible, således at forståelsen af sætningsbetydningen er afhængig af, at man bruger de syntaktiske signaler.

\subsection{Undersøgelse af teksters syntakskompleksitet}

Der er lavet en række undersøgelser af læremidlers sproglige kompleksitet, typisk med det overordnede formål at vurdere, hvilke tekster der passer til hvilke klassetrin eller individuelle elever. Undersøgelserne indeholder mål for syntaktisk kompleksitet, der er lette at opgøre automatisk, typisk helsætningslængde eller antallet af over- og underordnede sætninger pr. helsætning (Cunningham et. al. 2005, Hatcher 2000, Sheehan et al. 2010). Alt andet lige vil generelle og letberegnelige mål være at foretrække, hvis formålet alene er at estimere en teksts læsbarhed. Hatcher (2000) fandt, at antal ord i længste sætning forklarede $46 \%(r=0,68)$ af variationen i ekspertvurderinger af tekstmæssig sværhedsgrad. (JT fandt sammenblandingen af " $\mathrm{r}$ " og "variationen"। (=r^2) potentielt forvirrende) Når andre letberegnelige indikatorer såsom antal lange ord og boglængde blev inddraget, kunne $83 \%$ af variationen i bøgernes sværhedsgrad forklares (se også Cunningham et al. 2005). Der er således begrænset variation i bøgers sværhedsgrad tilbage at forklare med optælling af andre syntakselementer, fx forekomster af passiver, som også er mere arbejdskrævende at registrere. Så det er usikkert, om det i praksis er besværet værd yderligere at inddrage ikke-auto- 
matiserbare syntaktiske analyser, hvad angår læsbarhedsindekser. Der mangler imidlertid stadig mere detaljerede analyser af mængder af undervisningstekster med det formål at vurdere, i hvilket omfang elever konfronteres med krævende syntaktiske elementer.

\subsection{Opsummering af undersøgelsens formål}

Den følgende undersøgelses formål var at identificere og opgøre udbredelsen af en række krævende syntaktiske elementer i en stikprøve af danskfagets tekster rettet mod ind-, mellem- og udskolingen. Ud over uvante konstruktioner opgjorde vi en række relevante syntaktiske karakteristika, som er nævnt i litteraturen om sproglig tilgængelighed, og som i vores analyse blev grupperet inden for kategorierne kompleksitet og sproglig økonomisering.

Som nævnt er visse uvante konstruktioner, fx passiver, OVS-strukturer og relativsætninger, hvor relativet har anden funktion end subjekt, ofte brugt i psykolingvistiske undersøgelser, hvor de har vist sig at volde vanskeligheder, men nok kun hvis sætningsbetydningen ikke kan regnes ud ud fra viden om verden (semantisk reversible sætninger). Derfor havde undersøgelsen også til formål at opgøre, hvor stor en andel af disse konstruktioner der var reversible, for at vurdere, hvor godt materialerne i de psykolingvistiske forsøg afspejler elevers tekstlige hverdag.

\section{METODE}

\subsection{Tekstmateriale}

Vi udvalgte i første omgang uddrag af lærebøger, som er forfattet eller redigeret med tanke på bestemte klassetrin: 3. klasse (indskoling), 5 . klasse (mellemtrin) og 8. og 9. klasse (udskoling). Dertil udvalgte vi uddrag af digitale læremidler fra Gyldendals fagportaler til dansk i 3. til 6. klasse og dansk i 7. til 9. klasse samt portalerne danskidybden. gyldendal.dk og fagbog.gyldendal.dk, der begge indeholder udskolingsrettede læremidler. Lærebøgerne og de digitale læremidler (som vi i det følgende refererer samlet til som lerebøger) var alle faglitterære med undtagelse af et enkelt uddrag til 3. klasse (May \& Arne-Hansen 2007), hvori der indgår en kort fortælling (græsk myte genfortalt af forfatterne).

Dernæst udvalgte vi fag- og skønlitterære omverdentekster, dvs. tek- 
ster der ikke som lærebøgerne er forfattet til grundskolens danskfag, men findes i elevernes omverden, fx litteratur og avisartikler, og kan inddrages som læsestof i faget. Vi udvalgte både hele tekster ( $\mathrm{fx}$ avisartikler) og tekstuddrag (af $\mathrm{fx}$ romaner), som vi vurderede til at matche de afgrænsede klassetrin, enten med afsæt i forlagets målgruppespecificering ( $\mathrm{fx}$ 'ungdomsroman' eller 'Kanon i folkeskolen. Dansk. 1.-3. klasse') eller ud fra en vurdering af tekstindholdet og vores kendskab til skolepraksis, $\mathrm{fx}$ at man i udskolingens danskundervisning også læser avisartikler med tematisk relevans for forskelligt emnearbejde. Der kan imidlertid ligge forskellige pædagogiske overvejelser til grund for, hvilke omverdentekster dansklærere vælger til forskellige klassetrin. Forholdsvis svære tekster kan således i praksis indgå på lavere klassetrin, hvis læreren tilrettelægger tekstaktiviteter, der støtter forståelsen. En samlet tekstoversigt kan ses i bilag A.

Tabel 1 giver et overblik over datamaterialet. Første kolonne angiver antallet af tekster og perioder for alle tekster på tværs af teksttyper og klassetrin. De følgende kolonner opdeler opsummeringen på teksttyper og klassetrin. Overskrifter er ikke inkluderet i analyserne.

TABEL 1. OVERSIGT OVER TEKSTMATERIALE

\begin{tabular}{lccccccccc}
\hline \hline & & \multicolumn{3}{c}{ Lærebøger } & & \multicolumn{3}{c}{ Omverdentekster } \\
\cline { 3 - 4 } & Alle & Indskoling & Mellemtrin & Udskoling & & Indskoling & Mellemtrin & Udskoling \\
\hline Antal tekster & 23 & 4 & 4 & 5 & & 3 & 3 & 4 \\
Antal perioder & 1636 & 285 & 279 & 332 & & 148 & 219 & 373 \\
\hline \hline
\end{tabular}

\subsection{Analyseelementer og fremgangsmåde}

Hver tekst blev inddelt i perioder (dvs. en enhed, der består af en eller flere sætninger eller sætningslignende konstruktioner, og som afsluttes af punktum eller andet tungt pausetegn som udråbs-, spørgsmålstegn og semikolon), og hver periode blev mærket for tilstedeværelsen af de udvalgte analyseelementer. Tabel 2 giver en oversigt over disse elementer. De enkelte analyseelementer defineres nærmere i detailgennemgangen af resultaterne for de enkelte kategorier i de respektive underafsnit til afsnit 3 nedenfor. Valget af analyseelementer tog afsæt i litteraturen om syntaktisk tilgængelighed og syntaksforståelse nævnt ovenfor i afsnittene om krævende syntaks og undersøgelse af teksters syntaktiske 
kompleksitet. Analyseelementerne fordelte vi i kategorierne uvante konstruktioner, kompleksitet og sproglig økonomisering, som vi har redegjort for i de indledende afsnit.

TABEL 2. OVERSIGT OVER ANALYSEELEMENTER

\begin{tabular}{|c|c|c|}
\hline Uvante konstruktioner & Kompleksitet & Sproglig økonomisering \\
\hline $\begin{array}{l}\text { - } \\
\text { Oassivkonstruktioner } \\
\text { ObS-strukturer, hvor } \\
\text { objektet står i sætnin- } \\
\text { gens forfelt }\end{array}$ & $\begin{array}{l}\text { - } \quad \begin{array}{l}\text { pennemsnitlig } \\
\text { periodelængde }\end{array} \\
\text { Gennemsnitligt antal } \\
\text { neksi per periode }\end{array}$ & $\begin{array}{l}\text { - Genbrug: } \\
\quad \text { Flere verbaler eller } \\
\text { elliptiske sætninger } \\
\text { deler samme subjekt }\end{array}$ \\
\hline $\begin{array}{l}\text { Relativsætninger hvor } \\
\text { det relative element } \\
\text { ('som' eller udeladt/Ø) } \\
\text { har anden funktion } \\
\text { end subjekt, fx objekt, } \\
\text { subjektsprædikativ eller } \\
\text { styrelse i en præpositi- } \\
\text { onsforbindelse }\end{array}$ & $\begin{array}{l}\text { - Sætningsforvægt, dvs. } \\
\text { når der står et eller flere } \\
\text { lange led før sætnin- } \\
\text { gens hovedverbum } \\
\text { - } \quad \begin{array}{l}\text { Opadgånde sætninger, } \\
\text { dvs. med bevægelse } \\
\text { opad i sætningsgrad }\end{array} \\
\text { - Tunge led med ind- } \\
\text { skudt ledsætning }\end{array}$ & $\begin{array}{l}\text { Flere sideordnede } \\
\text { sætningsled } \\
\text { - Sætningsemner, dvs. } \\
\text { sætningslignende kon- } \\
\text { struktioner som enten } \\
\text { mangler subjekt eller } \\
\text { finit verbum } \\
\text { - } \quad \text { Verbalsubstantiver }\end{array}$ \\
\hline
\end{tabular}

\section{ANALYSE OG RESULTATER}

Tabel 3 viser den gennemsnitlige periodelængde, det gennemsnitlige antal neksusforhold i perioderne og procentandelen af perioder med mindst en af de øvrige analyseelementer. I første talkolonne findes en opgørelse på tværs af alle tekster. Til højre er opgørelserne opdelt i teksttype og klassetrin. Fx indeholder $18 \%$ af alle perioder i materialerne opadgående sætninger (se afsnit 3.7 nedenfor). I lærebogsteksterne til indskolingen indeholder $12 \%$ opadgående sætninger mod $21 \%$ i udskolingens omverdentekster. 


\begin{tabular}{|c|c|c|c|c|c|c|c|c|c|}
\hline \multirow[b]{2}{*}{ Analysekategori } & \multirow[b]{2}{*}{ Alle } & \multicolumn{4}{|c|}{ Lærebog } & \multicolumn{4}{|c|}{ Omverden } \\
\hline & & $\begin{array}{l}\text { Lære- } \\
\text { bog } \\
\text { total }\end{array}$ & $\begin{array}{l}\text { Ind- } \\
\text { skoling }\end{array}$ & $\begin{array}{l}\text { Mellem- } \\
\text { trin }\end{array}$ & $\begin{array}{l}\text { Ud- } \\
\text { skoling }\end{array}$ & $\begin{array}{l}\text { Om- } \\
\text { verden } \\
\text { total }\end{array}$ & $\begin{array}{l}\text { Indsko- } \\
\text { ling }\end{array}$ & $\begin{array}{l}\text { Mellem- } \\
\text { trin }\end{array}$ & Udskoling \\
\hline \multicolumn{10}{|l|}{$\begin{array}{l}\text { Uvante kon- } \\
\text { struktioner }\end{array}$} \\
\hline Passiver & $6 \%$ & $6 \%$ & $7 \%$ & $4 \%$ & $6 \%$ & $5 \%$ & $3 \%$ & $5 \%$ & $7 \%$ \\
\hline OVS & $8 \%$ & $6 \%$ & $6 \%$ & $8 \%$ & $3 \%$ & $10 \%$ & $7 \%$ & $16 \%$ & $8 \%$ \\
\hline $\begin{array}{l}\text { Relativsætninger } \\
\text { med ikke- } \\
\text { subjekt }\end{array}$ & $7 \%$ & $9 \%$ & $5 \%$ & $7 \%$ & $15 \%$ & $4 \%$ & $3 \%$ & $5 \%$ & $5 \%$ \\
\hline \multicolumn{10}{|l|}{ Kompleksitet } \\
\hline Periodelængde & 13,72 & 13,2 & 11,72 & 11,35 & 16,02 & 14,36 & 14,95 & 15,1 & 13,7 \\
\hline $\begin{array}{l}\text { Neksi pr. } \\
\text { periode }\end{array}$ & 2,25 & 2,19 & 1,99 & 1,96 & 2,55 & 2,33 & 2,24 & 2,62 & 2,2 \\
\hline Forvægt & $9 \%$ & $5 \%$ & $5 \%$ & $5 \%$ & $6 \%$ & $13 \%$ & $9 \%$ & $16 \%$ & $13 \%$ \\
\hline $\begin{array}{l}\text { Opadgående } \\
\text { sætninger }\end{array}$ & $18 \%$ & $13 \%$ & $12 \%$ & $10 \%$ & $16 \%$ & $24 \%$ & $19 \%$ & $32 \%$ & $21 \%$ \\
\hline $\begin{array}{l}\text { Tunge led med } \\
\text { indskud }\end{array}$ & $2 \%$ & $1 \%$ & $1 \%$ & $1 \%$ & $2 \%$ & $2 \%$ & $1 \%$ & $0 \%$ & $3 \%$ \\
\hline \multicolumn{10}{|l|}{ Økonomisering } \\
\hline Genbrug & $16 \%$ & $13 \%$ & $10 \%$ & $10 \%$ & $19 \%$ & $18 \%$ & $22 \%$ & $19 \%$ & $17 \%$ \\
\hline Sætningsemner & $4 \%$ & $3 \%$ & $1 \%$ & $6 \%$ & $2 \%$ & $6 \%$ & $1 \%$ & $6 \%$ & $8 \%$ \\
\hline $\begin{array}{l}\text { Verbal- } \\
\text { substantiver }\end{array}$ & $14 \%$ & $20 \%$ & $12 \%$ & $18 \%$ & $27 \%$ & $7 \%$ & $1 \%$ & $6 \%$ & $10 \%$ \\
\hline
\end{tabular}

Procenterne angiver andelen af perioder, der indeholder syntakselementet. Af tabellen fremgår det, at alle de krævende elementer findes på tværs af klassetrin. Derudover er det overordnede billede, at forekomsten af nogle former for krævende syntaks stiger op gennem skoletiden. Udviklingen er dog kun markant i få tilfælde, fx ved verbalsubstantiver, hvor andelen af perioder med sådanne stiger fra $12 \%$ i indskolingens lærebogstekster til $27 \%$ i udskolingen, og fra $1 \%$ til $10 \%$ i omverdentekster. Man skal være varsom med at lægge for meget i enkelttal for bestemte klassetrin, da hvert trin kun er repræsenteret af et begrænset antal tekster. Så vidt vi ved, findes der heller ikke undersøgelser eller skalaer med etablerede tærskelværdier for krævende syntaks at holde resultaterne op imod, og derfor bliver analysen overvejende deskriptiv. 


\subsection{Passivkonstruktioner}

Der findes som nævnt en del undersøgelser, der viser, at passiver kan give forståelsesvanskeligheder, i hvert fald hvis de er semantisk reversible (Ferreira 2003, Grandjean \& Poulsen 2017, Street \& Dabrowska 2010, Slobin 1966). Tabel 3 viser, at $6 \%$ af perioderne indeholdt passivsætninger. Elever møder således passivkonstruktioner i et vist omfang. Yderligere analyser viste, at kun $12,5 \%$ af passiverne udtrykte agens (eller hvilken rolle der ellers udtrykkes af subjekt i aktiv). Passiverne lod således i teksterne primært til at blive brugt til at udelade en overflødig agentrolle. Agens kan være overflødig, fordi den fremgår af konteksten:

(11) Når redderen giver tegn til hjælperen på land, trækkes redderen og den forulykkede ind i et roligt tempo. (Jørgensen 2006: 9)

Eller fordi agens er uvigtig:

(12) Det gamle plejehjem blev kaldt "kassen" [...]. (Haller 2011: 13)

Nærmere analyser viste, at $19 \%$ af passiverne var semantisk reversible. Sætningerne blev regnet for reversible, hvis subjektet var mulig agens, og hvis evt. agens i passiven kunne være patiens. Muligheden blev vurderet ud fra generel viden om verden, ikke ud fra en detaljeret forståelse af den specifikke kontekst. I (11) er redderen og den forulykkede begge mulige agensroller for en trække-handling. Reversibilitet er dog meget vanskeligt at bedømme entydigt, da det er svært at afgøre, hvad læsere med forskellig baggrundsviden kan basere sandsynlighedsvurderinger på. Så tallet skal tages med forbehold. En avanceret læser med god baggrundsviden og indlevende forståelse af den læste tekst vil muligvis opleve færre sætninger som semantisk reversible.

For langt de fleste passiver er der således andre ledetråde end syntaktiske signaler til at støtte fortolkningen af de semantiske roller (13).

(13) Sønnen forledes af spænding og fart til at stige højere og højere mod himlen. (May \& Arne-Hansen 2007: 137) 
Sætningen har en passivkonstruktion, der syntaktisk etablerer spending og fart som det, der forleder det grammatiske subjekt sønnen. Men også her kan viden om verden støtte den rette forståelse: Det er mere oplagt, at det er spanding og fart, der forleder sønnen end omvendt, så læseren er ikke nødvendigvis afhængig af at kunne afkode den syntaktiske information i sætningen. Det aktuelle eksempel kræver imidlertid, at man har en god forståelse af verbet forlede. Det gælder formentlig for en mere avanceret læser. Men det er måske ikke alle elever i 3. klasse, som teksten er tiltænkt, der har tilstrækkeligt ordkendskab til at overflødiggøre syntaksen. En væsentlig pædagogisk pointe er, at sådanne sætninger måske egner sig til nærmere gennemgang i klassen. Den teoretiske pointe er dog stadig, at der ved et flertal af passiver i lærebogsteksterne er information til stede, som gør, at læserne ikke er helt overladt til syntaksen i forståelsen af sætningerne.

\subsection{Objekt i satningens forfelt (OVS)}

På dansk forekommer rækkefølgen subjekt-verbal-objekt (SVO) hyppigere end objekt-verbal-subjekt (OVS), særligt i skriftsprog (Thomsen $\&$ Kristensen 2014). Læsere kan derfor have en begrundet forventning om, at præverbale nominaler skal tolkes som subjekt, og det kan nødvendiggøre en omtolkning, hvis rækkefølgen er OVS:

(14) Din selvfremstilling på nettet kalder vi din digitale identitet. (May \& Arne-Hansen 2015: 77, kildens kursivering)

Tabel 3 viser, at $8 \%$ af perioderne indeholdt objekter i forfeltet. Men sætningerne med OVS indeholdt også hv-spørgsmål (15) og forskellige former for (in)direkte tale med efterstillet anførende udtryk (16). Der kan være grunde til at tro, at disse strukturer udgør en mindre udfordring i læserens forarbejdning. Det er standard i hv-spørgsmål, at hv-leddet står i forfeltet, dvs. også hv-objekter, og efterstillede anførende udtryk har næsten karakter af tag-tilføjelse, så det er uklart, om disse forarbejdes som fulde matrixsætninger.

(15) Hvilke profiler har I på nettet? (May \& Arne-Hansen 2015: 78)

(16) “Der er han jo,” råbte de. (Bülow-Olsen et al. 2010: 17) 
Hv-spørgsmål og (in)direkte tale repræsenterer i hvert fald ikke den type konstruktioner, der volder vanskeligheder i de tidligere nævnte psykolingvistiske test af syntaksforståelse. Frasorteres hv-spørgsmål og (in)direkte tale, var det kun 1,3\% af perioderne i korpusset, der havde OVS-struktur. Ingen af dem var klart semantisk reversible, og mange af dem var korte:

(17) Ordet tekst kender du. (May \& Arne-Hansen 2007: 132)

Vi fandt kun ét eksempel på en OVS-struktur, hvor to argumenter måske kunne betragtes som mulig agens for verbet, dvs. at sætningen var semantisk reversibel:

(18) Og sådan en søn og tronfølger kunne kongen af Kreta selvfølgelig ikke have. (May \& Arne-Hansen 2007: 135)

Men selv her kan viden om verden støtte, da det nok er mere oplagt, at en bestemt konge kan have tanker om, hvilken slags søn og tronfølger der er passende, end omvendt.

Der var altså ingen klare eksempler på den type semantiske reversible sætninger, som man finder i psykolingvistiske forsøg, men vi kunne se, at eleverne møder OVS-strukturen i et vist omfang.

\subsection{Relativsatninger, hvor det relative element har anden funktion end subjekt} Også i relativsætninger kan der være ikke-kanonisk ledrækkefølge, hvor fx objektet kommer før subjektet. Som tidligere nævnt har sådanne sætninger vist sig vanskelige at forarbejde i psykolingvistiske forsøg (Grandjean \& Poulsen 2017, Wells et al. 2009). Tabel 3 opgør andelen af relative ledsætninger per periode, hvor det relative element (som eller $\varnothing$ ) havde en anden funktion end subjekt, fx styrelse:

(19) Nogle personer, som du har lyst til at høre mere om. (Dahlberg u.å)

$7 \%$ af perioderne indeholdt relativsætninger, hvor det relative element ikke var subjekt. Af de $7 \%$ var $68 \%$ objektrelativsætninger, hvor elementets funktion således var objekt: 
(20) Alligevel udtrykkes der fra ledelsen forståelse for den ekstreme sensitivitet, som den pågældende udviser [...]. (Bentsen \& Rex 2019)

En nærmere analyse viste, at ingen af objektrelativsætningerne var klart semantisk reversible.

\subsection{Gennemsnitlig periodelangde}

Øget længde kan potentielt udfordre læserens forståelse. Jo længere en periode bliver, desto flere tunge sætningsled skal læseren identificere og integrere med hinanden. Vi afgrænsede en periode som en enhed, der består af en eller flere sætninger eller sætningslignende konstruktioner, og som er afsluttet af punktum eller andet tungt pausetegn som udråbs-, spørgsmålstegn og semikolon.

Tabel 3 viser, at omverdenteksternes gennemsnitlige periodelængde er forholdsvis ens på tværs af klassetrin (mellem ca. 12 og 16 ord pr. periode). Blandt lærebogsteksterne ses dog en lille tendens til øget periodelængde fra mellemtrinnet til udskolingen. Det kunne understøtte en antagelse om, at lærebøger netop er skrevet til specifikke klassetrin, og at forfattere og redaktører gør sig overvejelser om længde. Dog er det væsentligt at understrege, at elever i 3. klasse ikke forskånes for lange perioder, ligesom der også i tekstuddragene til udskolingen findes eksempler på skrivestil præget af korte perioder.

Selvom periodelængde kan være et mål, der kvalificerer tekstvurderingen, må man i praksis være opmærksom på kvalitative forskelle. Det er ikke ligegyldigt, hvad periodelængden skyldes. Fx må lange perioder formodes lettere at forstå, når længden primært er betinget af sideordning (21) frem for underordning (22):

(21) Han kiggede på vattet, afgjorde, at det ikke var godt at spise, løb hele vejen rundt om bordet, satte sig på bagbenene og ordnede pelsen, kløede sig og sprang op på den lille drengs skulder. (Kipling 2015: 126) 
"Personligt tog jeg en samtale med hende, hvor jeg bakkede hende op og roste hende for det mod, hun viste ved som postdoc at reagere i en forsamling med professorer og andre, der var højere i hierarkiet," siger Mads Mordhorst, som oplyser, at den person, der var ansvarlig for sangvalget, endvidere var i samtale med underviseren. (Winther 2018)

\subsection{Gennemsnitligt antal neksi per periode}

En periode kan blive udfordrende, hvis den formidler mange meninger indlejret i eller sidestillet med hinanden. Vi operationaliserede denne idé ved at opgøre det gennemsnitlige antal neksi pr. periode. Neksus dækker over alle fuldstændige og reducerede neksusrelationer, som læseren skal identificere inden for en periodegrænse. Vi medtog således helsætnings-, ledsætnings- og infinitivneksus og elliptiske konstruktioner med reduceret neksus (subjekt eller verbal udeladt). Desuden medregnede vi infinitivkonstruktioner i analysen, idet vi betragter sådanne konstruktioner som en form for reducerede ledsætninger med implicit neksusrelation:

(23) I dette forløb skal du lere at argumentere og deltage i en mundtlig debat. (Fougt, Lorentzen \& Taagehøj 2017: 134; vores fremhævning af $i$ alt tre neksi, herunder to infinitivkonstruktioner med implicit neksusrelation)

(24) Du kan vurdere, hvordan det går med at skimme og narlase, og om $d u$ er i god læsetræning, eller om $d u$ måske kunne gå i træningslejr. (Schultz u.å; vores fremhævning af i alt seks neksi, herunder to infinitivkonstruktioner med implicit neksusrelation)

Tabel 3 viser ikke nogen markant gennemsnitsforskel mellem læremiddeltekster til forskellige klassetrin. Der ses kun en lettere stigning fra de indskolings- og mellemtrinrettede læremiddeltekster (hhv.1,99 og 1,96 neksus pr. periode) til udskolingens læremiddeltekster $(2,55)$. Omverdenteksterne adskiller sig heller ikke væsentligt på tværs af klassetrin.

Idet der ikke kan noteres nogen markant stigning i gennemsnitlig neksuslængde op gennem klassetrinnenes tekster, er det som ved ana- 
lyseelementet periodelængde værd at bemærke, at eleverne ret tidligt i skoleforløbet kan komme ud for at læse tekster med nogenlunde samme gennemsnitlige neksusantal pr. periode, som man finder i læsetekster på højere klassetrin.

\subsection{Forvagt}

Jo mere information læseren skal forarbejde, før helsætningens hovedverbum identificeres, desto mere kan sætningsforståelsen potentielt udfordres (Dalby et al. 1989, Jacobsen \& Skyum-Nielsen 2007, Scott $\&$ Balthazar 2010). Den antagelse bygger på, at helsætningens hovedverbum udgør en kerne, som de øvrige led er knyttet til i forskellige dependensrelationer. Hovedverbet kan således anses som centralt for læserens forståelse af sætningens betydningsstruktur, og led, der introduceres før hovedverbet, må derfor i højere grad fastholdes i læserens hukommelse som løsrevne betydningselementer.

Ligesom Arnbak \& Gandil (2010) kategoriserede vi forfelter med mindst syv ord som bærere af forvægt (25). Den præcise grænse er dog arbitrær, jf. Arnbak og Gandil.

(25) Ikke engang hendes bare fodder mod stengulvet kunne høres.

(Brostrøm 2011; vores fremhævelse)

Tabel 3 viser, at $9 \%$ af helsætningerne indeholdt forvægt med hyppigst forekomst i mellemtrinnets (16\%) og udskolingens (13\%) omverdentekster. Når vi så nærmere på sætningerne med forvægt, viste det sig, at forvægten i omkring halvdelen af tilfældene var en følge af foranstillede adverbielle ledsætninger, imens den anden halvdel udgjordes af komplekse nominelle led, foranstillede replikker ved (in-)direkte tale og dertil i mindre omfang øvrige adverbielle led.

Foranstillede adverbielle ledsætninger (26) tjente typisk et informationsstrukturelt formål ved at skabe forbindelse til forudgående (kendt) tekstindhold.

(26) Han hørte hende hvisle rasende, da hun ikke ramte ham. [...] Nàr en slange bider, men ikke rammer, siger den aldrig noget. (Kipling 2015: 128-130; vores fremhævning) 
Komplekse nominelle led i forfeltet (25) fandtes på tværs af teksttyper, men i særligt større grad i omverdenteksterne til udskolingen. Her tegnede avisartiklerne fra Kristeligt Dagblad (Bentsen \& Rex 2019, Tulinius 2018, Winther 2018) sig for en del sætninger med præ- eller postmodificerede nominelle led, der angiver navne og formelle titler på artiklernes informanter.

(27) Charlotte Rørdam Larsen, lektor emeritus ved institut for kommunikation og kultur på Aarhus Universitet, synes, det er udmærket, at sange diskuteres. (Winther 2018)

Disse konstruktioner forekommer at være et typisk genretræk ved informationstæt faglitteratur eller journalistik, der sammenligner og beskriver (her: informanternes baggrund).

Forvægt betinget af foranstillede replikker kan måske være mindre krævende (28), idet det anførende udtryk (matrixsætningen) har præg af efterstillet tag-element.

(28) Den kvindelige, brune forsker følte sig både krænket og ikkeinkluderet, og fremover vil man derfor undlade at synge sangen, lyder det fra Mads Mordhorst [...]. (Bentsen \& Rex 2019)

I praksis er der således forskel på, hvad forvægt er betinget af, og hvor udfordrende forvægt på den baggrund kan formodes at blive for læseren. Men analysen viste, at elever på alle klassetrin møder forvægt i danskfagets tekster.

\subsection{Opadgående satninger}

Sætningerne i en periode kan have forskellige sætningsgrader (dvs. indlejringsniveau). Helsætningens matrixsætning har 0. grad, og underordnede ledsætninger fordeler sig herfra i forskellige nedrangerede sætningsgrader (Hansen 2006). Vi antog, at perioder, der indeholder opadgående sætninger (29), dvs. med bevægelse fra underordnet til overordnet sætning, er mere krævende end perioder, der kun bevæger sig nedad i sætningsgrad (30) (Jacobsen \& Skyum-Nielsen 2007, Dalby et al. 1989). 


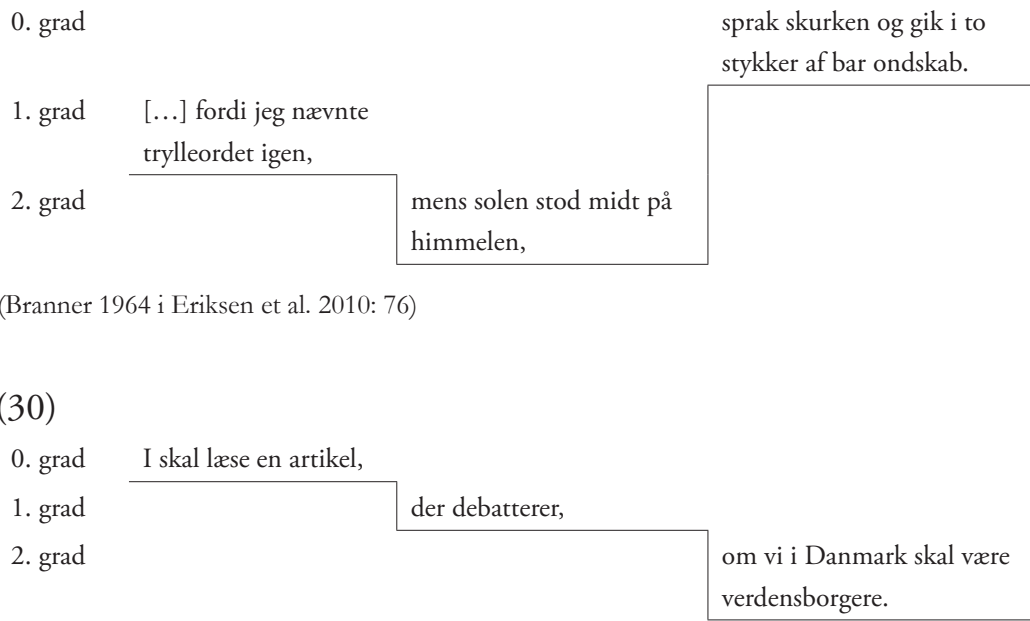

(Fougt, Lorentzen \& Taagehøj 2017: 141)

I analysen registrerede vi andelen af opadgående sætninger per periode. Som det fremgår af tabel 3, var opadgående sætninger gennemgående mere almindelige i omverdenteksterne (24\%) end i lærebøgerne (13 $\%)$. Det kan muligvis skyldes, at lærebøger er forfattet og redigeret med større læsepædagogisk opmærksomhed. Den højeste forekomst fandtes i omverdenteksterne til mellemtrinnet, hvor $32 \%$ af perioderne rummede opadgående sætninger. Uddragene tæller blandt andet danske oversættelser af Brødrene Løvehjerte (Lindgren 2011) og Junglebogen (Kipling 2015), der ved en nærmere optælling viste sig at indeholde hovedparten af de opadgående strukturer. Det understreger, at litterære værker, som læses på lavere klassetrin, sagtens kan overhale læsetekster til højere klassetrin i sætningskompleksitet.

\subsection{Tunge led med indskudt ledsatning}

Videre registrerede vi andelen af sætninger per periode, hvor tunge led med indskud i form af en eller flere ledsætninger adskilte en nominalkerne og et verbal: 
(31) Det nye plejehjem, som borgmesteren er så stolt over, fordi det er tegnet af en berømt arkitekt, bliver derfor kaldt "overkassen". (Haller 2011: 13)

Som det fremgår af tabel 3, forekom konstruktionen blot i $2 \%$ af tekstudvalgets perioder med nogenlunde ligelig fordeling på tværs af tekstgrupper og klassetrin.

En formidlingsmæssig gevinst ved denne type konstruktion er, at skribenten kan fylde mere information ind i sætningen uden at skulle konstruere flere sideordnede sætninger eller ty til eventuel (tung) præmodifikation af subjektkernen. Konstruktionen udfordrer dog potentielt læserens identifikation af sætningens betydningsstruktur ved at øge afstanden mellem matrixsætningens neksusdele med indskud af en anden neksusholdig konstruktion (Dalby et al. 1989, Scott \& Balthazar 2010).

\subsection{Genbrug}

Ofte økonomiserer skribenter med mængden af ord, således at sætningsled eller dele heraf udelades (ellipser). Fx kan flere verbaler eller elliptiske sætninger dele subjekt (32), eller flere sideordnede subjekter kan have fælles subjektsprædikat (33).

(32) Du skal lære om, hvordan forskellige medier ${ }_{\text {[subjekt] }}$ nermer $_{\text {[verbal 1] }}$ sig hinanden, lader ${ }_{\text {[verbal 2] }}$ sig påvirke af hinanden og måske ligefrem smelter $r_{\text {[verbal 3] }}$ sammen i en slags hybrider. (May \& ArneHansen 2015: 72; vores markeringer)

(33) Hvis [...], kan det ${ }_{\text {[forelobigt. subjekt] }}$ være en stor hjalp for dig ${ }_{\text {[subjektspredikat] }}$ at blive rigtig god til at bruge de forskellige modeller ${ }_{[\text {subjekt 1] }}$, og at vare meget bevidst om, hvor det kan betale sig at norlase i tekster med fagligt indhold ${ }_{[\text {subjekt 2] }}$. (Schultz u.å.; vores markeringer)

Der kan også være tale om flere styrelser, som deler præposition:

(34) I fagteksten her kan du læse om ${ }_{\text {[preposition] }}$ vores naboland Sverige [styrelse 1] $\mathrm{og}$ hvordan svenskerne lever [styrelse 2]. (Faurby 1999: 2; vores markeringer) 
Ved således at udelade identiske størrelser bliver udtrykket ikke unødigt langt eller gentagende. Genbrug er dog ensbetydende med mindre syntaktisk redundans, end man ville møde i fuldt udbyggede parallelle sætninger, og kræver, at læseren selv knytter de relevante tekstbånd. Derfor kan genbrug formodes at blive syntaktisk krævende. Vi er dog ikke bekendt med undersøgelser, der viser, at det faktisk er det.

Vi noterede andelen af de ovennævnte typer af genbrug i tekstkorpussets perioder. For sideordnede prædikater og styrelsers vedkommende noterede vi dog kun tilfælde, hvor mindst et af de sideordnede elementer indeholdt komplekst materiale, fx syntagme, ledsætning eller infinitivkonstruktion. Vi notererede således elementer bestående af enkeltord som ikke-komplekst materiale. Tabel 3 viser, at genbrug optrådte forholdsvis hyppigt (16\%) sammenlignet med de øvrige syntakskategorier.

Som nævnt kan genbrug have kommunikativ nytteværdi, og udeladte ord og sætninger vil ligeledes forkorte periodelængden. Det er således oplagt, at genbrug faktisk kan gøre syntaksen mindre krævende i nogle tilfælde. Omvendt kan både større antal og længde af sideordnede elementer øge de sideordnede elementers afstand til det, der genbruges, $\mathrm{fx}$ verbal eller præposition, og jo mere læseren derved skal på arbejde med syntaktisk at identificere sideordnede elementer, des mere krævende kan genbrug blive for forståelsen. Hvis sideordnede elementer består af forskelligt materiale (34), kan fraværet af parallelitet formentlig ligeledes gøre den syntaktiske økonomisering mere krævende, måske særligt for usikre læsere.

\subsection{Satningsemner}

Sætningsemner er sætningslignende konstruktioner, som mangler finit verbum eller subjekt og derved forudsætter, at læseren selv identificerer betydningsstrukturen ved at udnytte ledetråde i konteksten, fx verbal eller subjekt i en forudgående helsætning. Sætningsemner kan således betragtes som syntaktisk underspecificerende og i den henseende potentielt også være mere krævende konstruktioner.

(35) Der kom ogsaa flere Tilskuere. En gang imellem de fra Præsten, Frøkenen og Kapellanen. (Bang 2006: 579) 
Vi opgjorde andelen af sætningsemner i løbende tekst, dvs. at vi i denne sammenhæng så bort fra overskrifter og punktopstillinger uden kobling til forudgående sætning. Tabel 3 viser, at vi identificerede sætningsemner i $4 \%$ af perioderne, men med en vis variation mellem tekstgrupperne og mellem teksterne i de enkelte tekstgrupper. Forskellene synes i høj grad at bero på stilistiske valg hos forfatterne. Fx tegnede artiklerne fra Kristeligt Dagblad og uddraget fra novellen Vendt mod solen (Brostrøm 2011) sig for næsten alle forekomsterne i udskolingens omverdentekster.

\subsection{Verbalsubstantiver}

Verbalsubstantiver udtrykker et sætningslignende indhold, det vil sige med implicit proces og aktører. De dannes ved morfologisk afledning af en verbalstamme, fx 'betal-ing', der implicerer 'x betaler y' og substantiverer sagsforholdet, så det fremstilles uden den fysiske eller mentale dynamik, en sætning ville udfolde. Blandt andet derfor betragtes verbalsubstantiver ofte som krævende i fremstillinger om læsbarhed (Snow 2010).

$14 \%$ af perioderne indeholdt et eller flere verbalsubstantiver, men der var variation imellem de forskellige tekstgrupper, blandt andet med meget hyppig forekomst i udskolingens lærebøger (27\%) og en markant stigning i omverdenteksterne fra indskoling (1\%) til mellemtrin $(6 \%)$ og udskoling $(10 \%)$. Det tyder på, at tekster på højere klassetrin kan rumme en forholdsmæssig stor abstraktionsgrad på grund af verbalsubstantiver. I praksis skal man imidlertid tage højde for, at nogle verbalsubstantiver gentages flere gange i samme tekst, hvis de fx udgør nøglebegreber. I takt med at samme verbalsubstantiv optræder flere gange, må man formode at det gradvist bliver lettere at forarbejde.

\section{DISKUSSION}

Undersøgelsen af danskteksterne havde til formål at give indblik i, hvordan og hvor meget grundskoleelever konfronteres med krævende syntaks gennem en stikprøve af danskfagets tekster rettet mod indskoling, mellemtrin og udskoling. Indblik i dette omfang er som nævnt blandt andet relevant, fordi der er fundet relativt stærke korrelationer mellem elevers forstålse af uvante konstruktioner og elevernes generelle læseforståelse. 
Det overordnede billede var, at teksterne indeholdt uvante konstruktioner, som i psykolingvistiske forsøg og test har vist sig at være krævende: passiver ( $6 \%$ af perioderne), relativsætninger, hvor det relative element ikke er subjekt (7\%), og OVS-sætninger (1,3\%, eller $8 \%$, hvis spørgsmål og (in-)direkte tale medregnes). Disse strukturer udgør altså en del af skoleelevers skriftsproglige virkelighed. Men i modsætning til i psykolingvistiske forsøg var disse ikke-kanoniske strukturer i danskteksterne meget ofte semantisk irreversible, således at fortolkningen ikke afhang af syntaksen alene. På den måde afspejler sætningsmaterialet i de psykolingvistiske forsøg ikke direkte de udfordringer, elever møder i danskteksterne. Det virker derfor usandsynligt, at netop kendskab til de særlige, uvante konstruktioner er afgørende for elevernes forståelse af undervisningstekster generelt. En mere sandsynlig forklaring på de høje korrelationer mellem syntakstest og læseforståelse er nok, at uvante konstruktioner er gode til at afsløre gennemgående svagheder i elevernes evne til at bruge syntaktiske signaler i læsning. Brug af syntaktiske signaler kan være relevant ved alle typer krævende syntaks, både de uvante konstruktioner, men også ved forståelsen af opadgående sætninger eller lange perioder med mange informationer, der skal relateres rigtigt til hinanden. Vante eller simple strukturer er nok mindre gode til at afsløre svagheder, fordi alle finder dem så lette, at ingen svagheder afsløres.

Selvom kendskabet til specifikke konstruktioner nok ikke er afgørende for generel læseforståelse, så betyder det selvfølgelig ikke, at kendskab til dem er irrelevant. De indgår jo stadig i sproget og teksterne, og god udnyttelse af syntaktiske informationer kan muligvis også effektivisere forståelsen af selv irreversible sætninger.

Ud over uvante sætningskonstruktioner undersøgte vi andre slags krævende syntaks under overskrifterne kompleksitet og sproglig økonomisering. Førstnævnte dækkede dels teksternes gennemsnitlige periodemæssige længde og neksusmængde, dels forekomsten af forvægt, opadgående sætninger og tunge led med indskudt ledsætning. Analysen viste, at hverken den gennemsnitlige periodelængde eller neksusmængde steg markant op gennem klassetrinnenes dansktekster, hvilket peger på, at elever i 3. klasse således ikke forskånes for periodeomfang svarende til tekster på højere klassetrin. Forvægt forekom med større 
hyppighed i omverdenteksterne - særligt til mellemtrin og udskoling - end i lærebøgerne. Samme tendens så vi ved analyseelementet opadgående sætninger, mest markant med en periodemæssig hyppighed på $32 \%$ i omverdenteksterne til mellemtrinnet mod et samlet gennemsnit i lærebogsuddragene på $13 \%$. Med forbehold for stikprøvens begrænsede størrelse kan disse tendenser måske pege på, at lærebogsforfattere og -redaktører faktisk gør sig pædagogiske overvejelser om syntaktisk kompleksitet og $\mathrm{fx}$ begrænser forvægt og brug af opadgående sætninger. Tunge led med indskudt ledsætning var sjældnere forekommende på tværs af både teksttyper og klassetrin og syntes på den baggrund ikke at bidrage væsentligt til krævende syntaks i tekstkorpusset.

Sproglig økonomisering i form af genbrug, sætningsemner og verbalsubstantiver argumenterede vi for kan bidrage til en reduktion af den aflastningseffekt, syntaks kan have for læserens sprogforståelse. Genbrug var hyppigt forekommende på alle klassetrin, men hvorvidt genbrug bliver syntaktisk krævende for læseren, afhænger formentlig af både antal og omfang af de sætninger og sætningsled, der sidestilles som følge af genbrug, og af, om de sidestillede elementers materiale er ensartet. Men hvorvidt det faktisk forholder sig sådan, har vi ikke fundet undersøgelser, som giver svar på. Sætningsemner viste sig at have en forholdsvis begrænset forekomst i den løbende tekst i uddragene, og de syntes derfor ikke at bidrage væsentligt til krævende syntaks. Verbalsubstantiver var derimod væsentligt hyppigere repræsenteret, særligt i lærebogsteksterne, og markant hyppigere i både lærebogs- og omverdentekster til udskolingen sammenlignet med indskolingen.

Det er uvist, om den begrænsede udvikling op gennem klassetrinene ved nogle af analyseelementerne skyldes stikprøvens størrelse, eller om lærebogsforfattere og -redaktører faktisk gør sig pædagogiske overvejelser om syntaks og fx begrænser forvægt eller brug af opadgående sætninger. Analysen peger dog på, at elever i 3. klasse ikke i udpræget omfang forskånes for krævende syntaks, og viser samtidig, at forskellige former for krævende syntaks, fx forvægt og verbalsubstantiver, kan optræde med meget varierende hyppighed i hhv. lærebøger og omverdentekster til samme klassetrin.

Uanset hvilke forhold, der gør syntaksen krævende, vil øvrige tekstforhold som fx ordvalg og indholdsmæssig bekendthed ofte kunne tage 
brodden af krævende syntaks, måske endda overflødiggøre syntakssignaler i et vist omfang. Men i takt med, at tekster i indhold og opbygning bevæger sig længere væk fra, hvad eleverne er bekendte med, må man formode, at krævende syntaks kan få en tilsvarende større rolle at spille. Syntaks koder betydningsrelationer, og derved kan hurtig og sikker syntaksforarbejdning måske veje tungere i sprogforståelsen, hvis sproget eller indholdet på anden vis udfordrer læseren.

\section{PERSPEKTIVER FOR SYNTAKTISK OPM/ERKSOMHED I DANSKUNDERVISNINGEN}

Så vidt vi ved, eksisterer der hverken med dette eller andre studier klart empirisk belæg for enten at anbefale eller fraråde direkte undervisning i særlige krævende konstruktioner. Der findes ganske vist studier, der viser, at man kan blive bedre til at forstå bestemte konstruktioner gennem træning (Street \& Dabrowska 2010, Wells et al. 2009). Men det er stadig uklart, om forbedringerne overføres til aktiviteter, der ligger uden for en snæver psykolingvistisk testsituation. Under alle omstændigheder kan det nok være udmærket at sikre sig, at eleverne behersker fx passiv og forskellige former for relativkonstruktioner, der forekommer med nogen hyppighed, også med henblik på deres egne muligheder for at udtrykke sig varieret og præcist.

Der er som nævnt en mere sandsynlig mulighed for, at de høje korrelationer mellem syntakstest og læseforståelse skyldes, at nogle børn generelt har vanskeligt ved at udnytte syntaktiske signaler til at etablere sætningsbetydning (se også Grandjean og Poulsen 2017, Poulsen et al. under udgivelse). Det er derfor en interessant mulighed at undersøge om undervisning i redskaber til at begribe sætningsstruktur generelt kan have positive effekter på læseforståelse og skriftlig fremstilling. Der eksisterer begrænsede, men lovende, resultater med den slags undervisning for børn med udviklingsmæssige sprogforstyrrelser (Ebbels 2014). Det ville være interessant at undersøge, om den slags undervisning kan tilpasses den almene danskundervisning. I mellemtiden kan denne artikels inddeling og eksemplificering af forskellige slags potentielt krævende syntaks måske tjene som inspiration for, hvilke sætningskonstruktioner man kan vie lidt ekstra opmærksomhed i arbejdet med at forstå tekster. 
Martin Hauerberg Olsen, lektor

Københavns Professionshøjskole

mhau@kp.dk

Mads Poulsen, lektor

Institut for Nordiske Studier og Sprogvidenskab

Københavns Universitet

m.poulsen@hum.ku.dk

\section{LIT'TERATUR}

Arnbak, E. \& T. Gandil. 2010. Udvikling af et materiale til udredning af de faktiske lase- og skrivekrav på padagoguddannelsen. København: Statens Styrelse for Uddannelsesstøtte.

Balling, L.W. 2013. Does good writing mean good reading? An eye-tracking investigation of the effect of writing advice on reading. Fachsprache 1-2. 2-23.

Bang, H. 2006. Noveller. København: Gyldendal.

Bentsen, J. \& L. Rex. 2019. Markante politikere: Chokerende af CBS vil droppe ærkedansk højskolesang. Kristeligt Dagblad, 19. januar 2019. https://www.kristeligt-dagblad.dk/danmark/statsminister-chokerende-cbs-vil-forbyde-dansk-hoejskolesang (tilgået 18. november 2020).

Björnsson, C.H. 1971. Lasbarhed. København: Gads Forlag.

Branner, H.C. 2010 (1964). Den lille vilde busk fortæller. D. Eriksen, E. Larsen, J. Kurth \& L. Olsen, Kanon i folkeskolen. Dansk. 1.-3. klasse. Bind 1. 68-77. København: Alinea.

Brostrøm, M. 2011. Vendt mod solen. Gyldendal. https://danskidybden.gyldendal.dk (tilgået 18. november 2020).

Bülow-Olsen, L., S. Harms \& V. Skaarup. 2010. d'dansk. Fallesbog 5. klasse. København: Alinea.

Cunningham, J.W., S.A. Spadorcia, K.A. Erickson, D.A. Koppenhaver, J.M. Sturm \& D.E. Yoder. 2005. Investigating the instructional supportiveness of leveled texts. Reading Research Quarterly 40. 410-427. DOI: 10.1598/RRQ.40.4.2.

Dahlberg, N. u.å.. Hvem er Lille Frø? Gyldendal. https://dansk3-6.gyldendal.dk (tilgået 18 . november 2020).

Dalby, M., C. Elbro, M. Jansen \& T. Krogh. 1989. Teksters sproglige tilgængelighed. M. Dalby, C. Elbro, M. Jansen \& T. Krogh (red.), Bogen om lasning - set $i$ et udviklingsperspektiv, 376-399. København: Munksgaaard og Danmarks Pædagogiske Institut. 
Ebbels, S. 2014. Effectiveness of intervention for grammar in school-aged children with primary language impairments: A review of the evidence. Child Language Teaching and Therapy 30.7-40. DOI: 10.1177/0265659013512321

Fang, Z. 2012. Language correlates of disciplinary literacy. Topics in Language Disorders 32(1). 19-34. DOI: 10.1097/TLD.0b013e31824501de

Faurby, B. 1999. Sverige. Gyldendal. https://dansk3-6.gyldendal.dk (tilgået 18. november 2020).

Ferreira, F. 2003. The misinterpretation of noncanonical sentences. Cognitive Psychology 47. 164-203. DOI: 10.1016/S0010-0285(03)00005-7.

Fougt, S.S., R.F. Lorentzen \& M.J. Taagehøj. 2017. Kaliber dansk 8. København: Alinea.

Grandjean, D. \& M. Poulsen. 2017. Er syntaks en flaskehals i forståelsen? En undersøgelse af syntaksens betydning for børns lytte- og læseforståelse. NyS - Nydanske sprogstudier 52-53. 207-230. DOI: 10.7146/nys.v1i52-53.26264.

Haller, B. 2011. Skyld. København: Gyldendal.

Hansen, E. 2006. Demonernes Port. København: Hans Reitzels Forlag.

Hatcher, P. 2000. Predictors of Reading Recovery book levels. Journal of Research in Reading 23. 67-77. DOI: 10.1111/1467-9817.00103.

Ingemansson, J.M. \& T.J. Jensen. 2015. Passiven bør undgås - eller bør den? En receptionsundersøgelse af passivers indflydelse på forståelse af og holdninger til breve fra en offentlig myndighed. NyS - Nydanske Sprogstudier 49. 123-165. DOI: 10.7146/nys.v1i49.22906.

Jacobsen, H.G. \& P. Skyum-Nielsen. 2007. Dansk sprog. En grundbog. København: Schønberg.

Just, M.A. \& P.A. Carpenter. 1980. A theory of reading: From eye fixations to comprehension. Psychological Review 87. 329-354. DOI: 10.1037/0033295X.87.4.329.

Jørgensen, P.L. 2006. Sikkerhed ved vand. Rådet for Større Badesikkerhed. https:// dansk3-6.gyldendal.dk (tilgået 18. november 2020).

Karimi, H. \& F. Ferreira. 2016. Good-enough linguistic representations and online cognitive equilibrium in language processing. The Quarterly Journal of Experimental Psychology 69. 1013-1040. DOI: 10.1080/17470218.2015.1053951.

Kipling, R. 2015. Junglebogen. 2. udgave. Dansk oversættelse ved B. Brix. København: Forlaget Carlsen. 
Kizach, J., A. Nyvad \& K.R. Christensen. 2013. Structure before meaning: sentence processing, plausibility, and subcategorization. PLoS ONE 8: e76326. DOI: 10.1371/journal.pone.0076326.

Language and Reading Research Consortium \& J. Logan. 2017. Pressure points in reading comprehension: A quantile multiple regression analysis. Journal of Educational Psychology 109. 451-464. DOI: 10.1037/edu0000150.

Lindgreen, A. 2011. Brødrene Løvehjerte. Dansk oversættelse ved K. Bodenhoff. København: Gyldendal.

May, T. \& S. Arne-Hansen. 2007. Fandango 3. København: Gyldendal.

May, T. \& S. Arne-Hansen. 2009. Fandango 5. København: Gyldendal.

May, T. \& S. Arne-Hansen. 2015. Fandango 9. Vinkler på dansk. København: Gyldendal.

Poulsen, M., \& A.K.D. Gravgaard. 2016. Who did what to whom? The relationship between syntactic aspects of sentence comprehension and text comprehension. Scientific Studies of Reading 20. 325-338. DOI: 10.1080/10888438.2016.1180695.

Poulsen, M., J.L. Nielsen \& R. Vang Christensen. (Under udgivelse). Remembering sentences is not all about memory: Convergent and discriminant validity of syntactic knowledge and its relationship with reading comprehension. Journal of Child Language. DOI: 10.1017/S0305000921000210

Schultz, M. u.å. Faglig lesning 1. Gyldendal. https://dansk.gyldendal.dk (tilgået 18. november 2020).

Scott, M.C. \& H.C. Balthazar. 2010. The grammar of information: challenges for older students with language impairments. Topics in Language Disorders 30. 288-307. DOI: 10.1097/TLD.0b013e3181f90878.

Sheehan, K.M., I. Kostin, Y. Futagi \& M. Flor. 2010. Generating automated text complexity classifications that are aligned with targeted complexity standards. ETS Research Report Series 2010. i-44. DOI: 10.1002/j.2333-8504.2010.tb02235.x.

Silva, M.,\& K. Cain. 2015. The relations between lower and higher level comprehension skills and their role in prediction of early reading comprehension. Journal of Educational Psychology 107. 321-331. DOI: 10.1037/a0037769.

Slobin, D.I. 1966. Grammatical transformations and sentence comprehension in childhood and adulthood. Journal of Verbal Learning and Verbal Behavior 5. 219-227. DOI: 10.1016/S0022-5371(66)80023-3. 
Snow, C.E. 2010. Academic language and the challenge of reading for learning about science. Science 328. 450-452. DOI: 10.1126/science.1182597.

Sorensen Duncan, T., C. Mimeau, N. Crowel \& S.H. Deacon. (Under udgivelse). Not all sentences are created equal: evaluating the relation between children's understanding of basic and difficult sentences and their reading comprehension. Journal of Educational Psychology 113(2). 268-278 DOI: 10.1037/edu0000545.

Street, J.A. \& E. Dą̧browska. 2010. More individual differences in language attainment: How much do adult native speakers of English know about passives and quantifiers? Lingua 120. 2080-2094. DOI: 10.1016/j.lingua.2010.01.004.

Thomsen, D.B. \& L.B. Kristensen. 2014. Semantic role assignment in Danish children and adults. Acta Linguistica Hafniensia 46. 159-198. DOI: 10.1080/03740463.2014.990291

Thomsen, D.B. \& M. Poulsen. 2015. Cue conflicts in context: interplay between morphosyntax and discourse context in Danish preschoolers' semantic role assignment. Journal of Child Language 42. 1237-1266. DOI: 10.1017/ S0305000914000786.

Tulinius. B. 2018. Det store "vi” er kommet under pres. Kristeligt Dagblad, d. 16. november 2018. https://www.kristeligt-dagblad.dk/liv-sjael/det-store-vi-er-kommet-under-pres (tilgået 18. november 2020).

Uccelli, P., E. Phillips Galloway, C.D. Barr, A. Meneses \& C.L. Dobbs. 2015. Beyond vocabulary: Exploring cross-disciplinary academic-language proficiency and its association with reading comprehension. Reading Research Quarterly 50(3). 337-356. DOI: 10.1002/rrq.104.

Wells, J.B., M.H. Christiansen, D.S. Race, D.J. Acheson \& M.C. MacDonald. 2009. Experience and sentence processing: Statistical learning and relative clause comprehension. Cognitive Psychology 58. 250-271. DOI: 10.1016/j.cogpsych.2008.08.002.

Winther, T. 2018. Højskolesang førte til krænkelsessag på Handelshøjskolen i København. Kristeligt Dagblad, 18. december 2018. https://www.kristeligt-dagblad. $\mathrm{dk} /$ danmark/hoejskolesang-foerte-til-kraenkelsessag-paa-handelshoejskolen-i-koebenhavn (tilgået 18. november 2020). 
BILAG A

\begin{tabular}{|c|c|c|c|}
\hline & Indskoling & Mellemtrin & Udskoling \\
\hline Lærebogstekster & $\begin{array}{l}\text { Bülow-Olsen, L., Harms, S. } \\
\text { \& Skaarup, V. 2014. d'dansk. } \\
\text { Fallesbog 3. klasse. København: } \\
\text { Alinea. 66-64 og 76-72. } \\
\text { Dahlberg N. u.å.. Hvem er } \\
\text { Lille Fro? Gyldendal. https:// } \\
\text { dansk3-6.gyldendal.dk. Intro- } \\
\text { duktion samt sektionerne 'Mål', } \\
\text { '1. Hvad er en personkarak- } \\
\text { teristik?' og del A og B i '2. } \\
\text { Fortællingen om Lille Frø'. } \\
\text { Faurby, B. 1999. Sverige. } \\
\text { Gyldendal. https://dansk3-6. } \\
\text { gyldendal.dk. S. 2-6 samt } \\
\text { introducerende webtekst. } \\
\\
\text { May, T. \& Arne-Hansen, S. } \\
\text { 2007. Fandango 3. København: } \\
\text { Gyldendal. 132-139, 144-146. }\end{array}$ & $\begin{array}{l}\text { Billesbølle, S. u.å. Nar novellen. } \\
\text { Gyldendal. https://dansk3-6. } \\
\text { gyldendal.dk. Introduktion } \\
\text { samt sektionerne 'Mål' og del A } \\
\text { og B i 'Ind i genren'. } \\
\text { Bülow-Olsen, L., Harms, S. } \\
\text { \& Skaarup, V. 2010. d'dansk. } \\
\text { Fallesbog 5. klasse. København: } \\
\text { Alinea. 10-8 og 18-15. } \\
\text { Jensen, H. u.å. Emilie Sannom: } \\
\text { Europas dristigste luftakrobat } \\
\text { med tilhørende opgaver af D. } \\
\text { Kamstrup. Gyldendal. https:// } \\
\text { dansk3-6.gyldendal.dk. } \\
\text { Tekst samt opgavedel A og B. } \\
\text { May, T. \& Arne-Hansen, S. } \\
\text { 2009. Fandango 5. København: } \\
\text { Gyldendal. 6-7, 78-80, 87, } \\
\text { 97-100. }\end{array}$ & $\begin{array}{l}\text { Fought, S., Lorentzen, R. \& } \\
\text { Taagehøj, M. 2017. Kaliber } \\
\text { dansk 8. København: Alinea. } \\
\text { 138-148. } \\
\text { Henkel. A. \& Frydensbjerg, } \\
\text { J. 2018. Fuglen. Gyldendal. } \\
\text { https://danskidybden.gylden- } \\
\text { dal.dk 'Del 3: Analyse'. } \\
\text { May, T. \& Arne-Hansen, S. } \\
\text { 2015. Fandango 9. Vinkler på } \\
\text { dansk. København: Gyldendal. } \\
\text { 78-72. } \\
\text { Rasmussen, M. 2010. Glo- } \\
\text { balisering. Gyldendal. 16-17. } \\
\text { http://fagbog.gyldendal.dk/ } \\
\text { 'Den globale landsby' samt } \\
\text { læseforberedende afsnit 'Mål' } \\
\text { og 'Læs og organiser'. } \\
\text { Schultz, M. u.å.. Faglig lasning } \\
\text { 1. Gyldendal. https://dansk.gyl- } \\
\text { dendal.dk. Introduktion samt } \\
\text { sektionerne '1 Mål', '2. Tjek på } \\
\text { teksttypen' og '7. Evaluering'. }\end{array}$ \\
\hline $\begin{array}{l}\text { Omverden- } \\
\text { tekster }\end{array}$ & $\begin{array}{l}\text { Branner, H. C. 1964. Den lille } \\
\text { vilde busk fortæller. D. Eriksen } \\
\text { et al. 2010. Kanon i folkesko- } \\
\text { len. Dansk. 1.-3. klasse. Bind } 1 . \\
\text { 68-77. København: Alinea. } \\
\text { Eken, C. 2002. En drøm } \\
\text { om vinger. May, T. \& Arne- } \\
\text { Hansen, S. 2007. Fandango } \\
\text { 3. København: Gyldendal. } \\
\text { 140-141. } \\
\text { Jensen, L. 2000. } 100 \text { splin- } \\
\text { ternye historier. København: } \\
\text { Gyldendal. 20-29. }\end{array}$ & $\begin{array}{l}\text { Jørgensen, P. L. 2006. Sikker- } \\
\text { hed ved vand. Rådet for Større } \\
\text { Badesikkerhed. 3-11. } \\
\text { https://dansk3-6.gyldendal.dk. } \\
\text { Kipling, R. 2015. Junglebogen. } \\
\text { 2. udgave. Dansk oversættelse } \\
\text { ved B. Brix. København: Forla- } \\
\text { get Carlsen. 124-127. } \\
\text { Lindgreen, A. 2011. Brødrene } \\
\text { Løvehjerte. Dansk oversættelse } \\
\text { ved K. Bodenhoff. København: } \\
\text { Gyldendal. 3-4. }\end{array}$ & $\begin{array}{l}\text { Bang, H. 2006. Noveller. } \\
\text { København: Gyldendal. } \\
576-579 \text { ("Irene Holm" del } 1 \\
\text { og begyndelsen af del 2). } \\
\text { Bentsen, J. \& Rex, L. 2019. } \\
\text { Markante politikere: Chokeren- } \\
\text { de af CBS vil droppe ærkedankk } \\
\text { højskolesang. Kristeligt Dag- } \\
\text { blad d. 18. januar. 2019. } \\
\text { Brostrøm, M. 2011: Vendt } \\
\text { mod solen. Gyldendal. https:// } \\
\text { danskidybden.gyldendal.dk. } \\
\text { Første del: 'Apicale, den 20. } \\
\text { juli 1972'. } \\
\text { Haller, B. 2011. Skyld. Køben- } \\
\text { havn: Gyldendal. 9-14. } \\
\text { Tulinius. B. 2018. Det store } \\
\text { "vi” er kommet under pres. } \\
\text { Kristeligt Dagblad d. 16. } \\
\text { november 2018. } \\
\text { Winther, T. 2018. Højskolesang } \\
\text { førte til krænkelsessag på } \\
\text { Handelshøjskolen i København. } \\
\text { Kristeligt Dagblad d. 18. } \\
\text { december 2018. }\end{array}$ \\
\hline
\end{tabular}

